\title{
Serum procalcitonin: a reliable marker for the diagnosis of sepsis in children
}

\author{
Choudhury $\mathbf{J}^{1}$, Mohanty $\mathbf{D}^{2}$, Routray $\mathrm{SS}^{3}$ \\ ${ }^{1}$ Dr. Jasashree Choudhury, Associate Professor Department of Pediatrics, IMS \& SUM Hospital, BBSR, ${ }^{2}$ Dr. \\ Debaprasad Mohanty, Associate Professor, ${ }^{3}$ Dr. Sidharth Sraban Routray, Assistant Professor. All are affiliated with \\ Department of Anaesthesiology and Critical Care, SCB Medical College, Hospital. Cuttack, Odisha, India
}

Address for correspondence: Dr. Jasashree Choudhury, Email: drjasashree@gmail.com

\begin{abstract}
Objective: Diagnosis of sepsis in children should be done at the earliest so that appropriate treatment can be started. Though, serum procalcitonin has been studied as an early maker of sepsis still it is not recommended in sepsis guideline because of variable result. In this study, we studied the role of serum procalcitonin in establishing the diagnosis of sepsis in children. Materials \& Methods: Blood samples were collected at admission from 60 children admitted to the central Intensive Care Units at SCB Medical College, Hospital Cuttack from August 2014 to November 2015. Patients were categorized into different groups according to clinical symptoms of sepsis, bacteriological and laboratory data. Group I consisted of 20 children with positive blood cultures and other biological parameters suggesting infection. Group II consisted of 20 children with negative blood cultures but had two or three of clinical symptoms of sepsis. The control group included 20 healthy children with no clinical and biological data suggesting infection. Sreum procalcitonin were determined by immunoluminometric assay method. Results: Mean levels of procalcitonin in septic children (group I) were significantly higher than the other two groups $(\mathrm{P}<0.005)$. Sensitivity, specificity, positive predictive value and negative predictive value were determined for all markers and analyzed and compared with each other. Conclusion: We concluded that serum procalcitonin was a better marker than $\mathrm{C}$ - reactive protein in the diagnosis of sepsis in children.
\end{abstract}

Key Words: C- reactive protein, Sepsis, Procalcitonin.

\section{Introduction}

Worldwide sepsis is a common cause of morbidity and mortality in children. Rapid diagnosis and treatment of systemic bacterial infection is essential, for better patient outcome $[1,2]$.

Clinical signs of systemic inflammation including changes in body temperature, tachycardia and routine laboratory parameters like leukocytosis and $\mathrm{C}$ - reactive protein (CRP) are used for diagnosis of sepsis [3]. Due to variable signs and symptoms of sepsis, the diagnosis of sepsis in children is quite difficult and can be misleading and sometimes critically ill children only show systemic inflammatory response syndrome (SIRS) without infection [4].

Elevated C- reactive Protein levels can be seen not only in infection, but also in autoimmune disease, in surgery,

Manuscript received: $18^{\text {th }}$ Dec 2015

Reviewed: $30^{\text {th }}$ Dec 2015

Author Corrected; $09^{\text {th }}$ Feb 2016

Accepted for Publication: $19^{\text {th }}$ Feb 2016 meconium aspiration and recent vaccination. Also the C-reactive Protein values do not rise significantly until almost 14-48 hr after the onset of infection [5].

Procalcitonin (PCT) has been proposed as a marker of bacterial sepsis in critically ill adult patients. Procalcitonin is a precursor of calcitonin and a 116 amino acids protein [6]. In contrast to calcitonin that has a short half life of $10 \mathrm{~min}$, procalcitonin has a much longer half-life as 25-30 hours [7]. In healthy persons, procalcitonin levels are barely detectable.

Bacterial lipopolysaccharide (LPS) has been shown to be a potent inducer of procalcitonin release into the systemic circulation. Procalcitonin concentration starts to rise from 3-4 hr after an endotoxin challenge, peak about $6 \mathrm{hr}$, and remain increased for over $24 \mathrm{hr}$ [8]. In this study, we compared the value of procalcitonin and C-reactive Protein, in establishing the early diagnosis of sepsis in children 


\section{Materials \& Methods}

This was a prospective observational study carried central Intensive Care Units at SCB medical college, Hospital Cuttack from August 2014 to November 2015. Children were excluded, those who had chronic systemic inflammatory diseases, degenerative neurological diseases, primary or acquired immunodeficiency diseases, or got antibiotics for more than 24 hours, suffered traumas or burns or those who were in postoperative care. Written consent was obtained from their parents or guardians before including their children in study.

Sepsis and septic shock were defined according the criteria established by the Consensus conference of 2012 [9]. Sepsis was defined as the presence of the signs and symptoms of SIRs associated with a documented infection. Diagnosis of SIRS was made based on the presence of two or more of the following criteria: 1) Temperature (rectal, oral or central) $>38.5^{\circ} \mathrm{C}$ or $<35^{\circ} \mathrm{C}$; 2) tachycardia (may be absent if there is hypothermia); 3) tachypnea; 4) total leukocyte count high or low for age (and not secondary to chemotherapy) or immature neutrophils numbering for more than $10 \%$ of count. In addition, at least one of the following had to be present: altered consciousness, hypoxemia, and increase in level of serum lactate or wide pulses.

Before initiation of antibiotic therapy in children suspected of sepsis, blood samples for blood culture, PCT and C-reactive Protein measurements were obtained by peripheral venous puncture.

Finally according to clinical symptoms of sepsis, microbiologic and laboratory results, children were classified in to three groups:

1. Proven sepsis $(n=20)$ : positive blood culture and clinical symptoms of sepsis.

2. Suspected sepsis $(\mathrm{n}=20)$ : with clinical symptoms but negative blood culture.

3. Control group $(n=20)$ : children with no clinical and biological data of infection were selected as the control group.

Statistical analysis: To compare means of the variables, one way ANOVA test was done by SPSS (version 16). Categorical variables between groups were analyzed using Chi-square test.

\section{Results}

In this study, 20 children with positive blood cultures and clinical sepsis (group I) and 20 children with suspected sepsis (group II) and 20 healthy children (group III) were enrolled. Blood culture was positive for all patient (group I). The identified bacteria included Staphylococcus aureus $(n=7)$, coagulase negative staphylococcus $(n=5)$ Streptococcus beta hemolytic group A $(n=4)$, Escherichia coli $(n=1)$, Pseudomonas aeruginosa $(n=2)$ and Enterobacter $(n=1)$. There was no statistical significance among the variable like age, sex and weight in all 3 groups

The mean of C-reactive Protein and procalcitonin is studied groups are shown in Table 1. There was a significant difference between the mean of $\mathrm{C}$ - reactive protein level of healthy controls and septic children ( $\mathrm{P}<0.05$, It was also observed significant difference between septic and suspected sepsis cases. $(\mathrm{P}<0.05)$.

Table 1: The mean and standard deviation of $\mathrm{C}$ - reactive protein and procalcitonin in different groups

\begin{tabular}{|l|l|l|l|}
\hline & Markers & Mean \pm SD & P-Value \\
\hline \multirow{4}{*}{ CRP mg/l } & Control group & $5.34 \pm 3.37$ & $\mathrm{P}<0.05$ \\
\cline { 2 - 4 } & Proved sepsis & $25.92 \pm 28.14$ & $\mathrm{P}<0.05$ \\
\cline { 2 - 4 } & Suspected sepsis & $10.45 \pm 11.48$ & $\mathrm{P}<0.05$ \\
\hline PCT ng/ml & Control group & $0.58 \pm 0.49$ & $\mathrm{P}<0.05$ \\
\cline { 2 - 4 } & Proved sepsis & $6.85 \pm 6.84$ & $\mathrm{P}<0.05$ \\
\cline { 2 - 4 } & Suspected sepsis & $3.45 \pm 6.15$ & $\mathrm{P}<0.05$ \\
\hline
\end{tabular}

C-reactive Protein concentration in 55\% of proved sepsis group was higher than the cut-off value. But in suspected sepsis only $20 \%$ of cases and in the control group only in $8 \%$ of infants, C-reactive Protein level was found higher than the cutoff value..

Procalcitonin level was significantly higher in septic and suspected children in comparison with the normal healthy children $(\mathrm{P}<0.05)$. The optimum cut-off value was $12 \mathrm{mg} / 1$ for $\mathrm{C}$ - reactive protein and $1.1 \mathrm{ng} / \mathrm{ml}$ for procalcitonin. 


\section{Discussion}

In recent years measurement of procalcitonin and other inflammatory mediators like lactate and C-reactive Protein have been reported as sensitive parameters for the early diagnosis and prognostication of sepsis in children. A variety of proinflammatory cytokines plays a role in pathogenesis of bacterial sepsis. Production of interleukin - 6 occurs before production of procalcitonin. These cytokines seems to trigger the procalcitonin secretion from target cells [10].

The increase in the serum concentration of $\mathrm{C}$ - reactive protein is rather slow during the first $24-48 \mathrm{hr}$ of infection which may negatively affect the sensitivity of the test. In addition, increase in $\mathrm{C}$ - reactive protein concentration in non-infected clinical conditions like in autoimmune disease, in surgery, meconium aspiration and recent vaccination may affect the specificity of the test [11].

Procalcitonin has been investigated for its diagnostic role in neonatal sepsis. It has been reported that high concentration of plasma procalcitonin was found in infants with severe infection, while procalcitonin levels were very low in those with no infections [12]. Many authors found that procalcitonin is a promising marker for the diagnosis of neonatal sepsis[7,8]. But some investigators questioned the diagnostic accuracy of procalcitonin in detecting the sepsis in children. In these studies, it was reported that serum levels is increased in non-infected neonates with perinatal asphyxia, intracranial hemorrhage, pneumothorax, or after resuscitation [13]. In the research of Chin Yi-ling et al (2004) sensitivity of $69.5 \%$ and specificity of $64.5 \%$ for procalcitonin were obtained and compared to $67.25 \%$ of sensitivity and $93.9 \%$ of specificity for C-reactive Protein [14]. Also, the results of study by Khoshdel et al (2008) showed that sensitivity, specificity and positive and negative predictive values of procalcitonin level for sepsis were $87.5 \%, 87.4 \%, 30.4 \%$ and $99.1 \%$ respectively [15]. The study of Zahedpasha et al (2009) showed that procalcitonin levels were high in neonates with proven sepsis and the levels dropped dramatically after treatment with antibiotics [16].

In the present study, among 20 children of proved sepsis, 4 cases has procalcitonin levels less than 1.1 $\mathrm{ng} / \mathrm{ml}$ (cut-off value). But in the control group, among 20 children, only 2 children had procalcitonin higher than $1.1 \mathrm{ng} / \mathrm{ml}$, may be due to physiological increase of proclacitonin, even in the absence of infection. Our results indicated that the sensitivity of procalcitonin
$(70 \%)$ was more than $\mathrm{C}$ - reactive protein $(45 \%)$ for the diagnosis of sepsis and procalcitonin appears to be useful marker for the severity of infection in children.

\section{Conclusion}

Serum procalcitonin levels on admission can be used to differentiate sepsis and septic shock, with greater level of significance. The results suggested that serum procalcitonin is not only an important tool for diagnosis of sepsis in children but also a useful marker to assess the severity of patients for prognostication.

\section{Funding: Nill \\ Conflict of Interest: None \\ Permission of IRB: Yes}

\section{Reference}

1. Barbara S. Infections of the neonatal infant. In: Behrman Re, Kliegman R, Jensen HB.editors. Nelson Textbook of Pediatrics. Philadelphia: WB saunders CO; 2008 pp. 794-811.

2. Young LS. Sepsis syndrome. In: Mandell GL, Bennett JE, Dolin R, editors. Principles and Practice of infectious Disease. Philadelphia: Churchill livingstone; 2005. Pp. 910-920.

3. Remington JS, Klein JO. Bacterial sepsis and meningitis. Infectious disease of the fetus and newnorn infant Philadelphia: W.B. Saunders Company; 2001.

4. Brun-Buisson $\mathrm{C}$. The epidemiology of the systemic inflammatory response. Intensive Care Med. 2000;26 Suppl 1:S64-74.

5. Black S, Kushner I, Samols D. C-reactive Protein. J Biol Chem. 2004 Nov 19;279(47):48487-90. Epub 2004 Aug 26.

6.Chiesa C, Panero A, Rossi N, Stegagno M, De Giusti M, Osborn JF, Pacifico L. Reliability of procalcitonin concentrations for the diagnosis of sepsis in critically ill neonates. Clin Infect Dis. 1998 Mar;26(3):664-72.

7. Vincent JL. Procalcitonin: THE marker of sepsis? Crit Care Med. 2000 Apr;28(4):1226-8.

8. Carrol ED, Thomson AP, Hart CA. Procalcitonin as a marker of sepsis. Int $\mathrm{J}$ Antimicrob Agents. 2002 Jul;20(1):1-9. 
9. Dellinger RP, Levy MM, Rhodes A, Annane D, Gerlach H, Opal SM, Sevransky JE, Sprung CL, Douglas IS, Jaeschke R, Osborn TM, Nunnally ME, Townsend SR, Reinhart K, Kleinpell RM, Angus DC, Deutschman CS, Machado FR, Rubenfeld GD, Webb SA, Beale RJ, Vincent JL, Moreno R; Surviving Sepsis Campaign Guidelines Committee including the Pediatric Subgroup. Surviving sepsis campaign: international guidelines for management of severe sepsis and septic shock: 2012. Crit Care Med. 2013 Feb;41(2):580-637. doi: 10.1097/CCM.0b013e31827e83af.

10. Mehr S, Doyle LW. Cytokines as markers of bacterial sepsis in newborn infants: a review. Pediatr Infect Dis J. 2000 Sep;19(9):879-87.

11. Kocabaş E, Sarikçioğlu A, Aksaray N, Seydaoğlu G, Seyhun Y, Yaman A. Role of procalcitonin, Creactive protein, interleukin-6, interleukin- 8 and tumor necrosis factor-alpha in the diagnosis of neonatal sepsis. Turk J Pediatr. 2007 Jan-Mar;49(1):7-20.
12. Athhan F, Akagündüz B, Genel F, Bak M, Can D. Procalcitonin: a marker of neonatal sepsis. J Trop Pediatr. 2002 Feb;48(1):10-4.

13. Janota J, Stranák Z, Bĕlohlávková S, Mudra $\mathrm{K}$, Simák J. Postnatal increase of procalcitonin in premature newborns is enhanced by chorioamnionitis and neonatal sepsis. Eur J Clin Invest. 2001 Nov;31(11):978-83.

14. Chan YL, Tseng CP, Tsay PK, Chang SS, Chiu TF, Chen JC. Procalcitonin as a marker of bacterial infection in the emergency department: an observational study. Crit Care. 2004 Feb;8(1):R12-20. Epub 2003 Nov 20.

15. Khoshdel A, Mahmoudzadeh M, Kheiri S, Imani R, Shahabi G, Saedi E, Taheri E, Motamedi R. Sensitivity and specificity of procalcitonin in diagnosis of neonatal sepsis. Iran J Pathol. 2008;3:203-207.

16. Zahedpasha Y, Ahmadpour KacholM, Hajiahmadi M, Haghshenas M. Procalcitonin as a marker of neonatal sepsis. Iran J Pediatr. 2009;19:117-122.

\section{How to cite this article?}

Choudhury J, Mohanty D, Routray SS. Serum procalcitonin: a reliable marker for the diagnosis of sepsis in children.

Pediatr Rev: Int J Pediatr Res 2016; 3(2):82-85.doi: 10.17511/ijpr.2016.i02.02.

